ІНФОРМАЦІЙНА БЕЗПЕКА В ДЕРЖАВНОМУ РЕГУЛЮВАННІ ЕКОНОМІЧНОÏ СТАБІЛЬНОСТІ ТА СТІЙКОСТІ

\title{
INFORMATION SECURITY IN STATE REGULATION OF ECONOMIC STABILITY AND PERSISTENCY
}

у статті розкрито взаємозв'язок між інфрормаційними й економічними чинниками, їхній вплив на економічну стабільність та стійкість. Державне регулювання в умовах інфрормаційної економіки відбувається в нових умовах виробництва, розподілу і споживання суспільних благ. Воно спирається па широке використання інорормаційно-комунікаційних технологій. Інформаційно-економічне середовище набуває все більшого значення, тому потребує захисту від несанкціонованого або ненавмисного впливу на рівні держави, регіону і навіть окремих під приємств. Комплексна інсрормаційна безпека виступає запорукою гарантування економічної безпеки. Зосередження фоккуса уваги на інфрормаційних аспектах забезпечення економічної стабільності та стійкості як основних умов прогресивного розвитку економіки, становить науковий інтерес щодо поглиблення знань, набуття умінь дієвого державного регулювання. Уведено поняття «інформаційно-економічна безпека»: комплексна система, що забезпечує захист життєво важливих інтересів громадян, суспільства та держави в економічній сорері від внутрішніх і зовнішніх інформаційних загроз. Останні в такому визначенні набувають статусу інфрормаційно-економічних загроз - сукупності умов, чинників і подій, яка визначає ефрективність внутрішніх і зовнішніх деструктивних інформаційних впливів на економічний стан країни.

Державне регулюванні економічної стабільності та стійкості розглянуте на основі аналізу ризиків сучасної економіки, як-от: інноваційні ризики, ризики, пов'язані із циклічністю розвитку економіки, ринкові ризики інфрормаційні ризики, інституціональні ризики. Зроблено висновки, що сучасний розвиток суспільства характеризується інтеграцією безпекових аспектів інформаційних та економічних прочесів, що переводить державне управління у сорері економіки на більш високий рівень за вимогами до ефективності. Взаємопроникнення інсрормаційної й економічної безпеки фрормує нову сферу наукових знань, що можуть бути задіяні для підвищення рівня стабільності та стійкості економіки. Удосконалення державного управління повинно включати: подолання декларативного характеру законодавства, скорочення розриву між законодавством i практикою в інформаційно-економічній сорері, створення нових інститутів, що визначають рамки взаємодії і правил поведінки щодо забезпечення стабільності та стійкості економіки.

Напрямом подальшого дослідження має стати визначення показників оцінки економічної безпеки, включаючи індикатори, що сигналізують про можливі небезпеки і загрози в інформаційній сфрері.

Ключові слова: інформаційна безпека, економічна безпека, інфрормаційно-економічна безпека, економічна стабільність, економічна стійкість.

The article presents the relationship between information and economic factors and their influence on economic stability and persistency. State regulation under conditions of the information economy takes place in the new conditions of production, distribution and consumption of public goods. It is based on the widespread use of information and communication technologies. The information and economic environment is becoming increasingly important, so it requires protection from unauthorized or unintentional influence at the level of the state, region, and even individual enterprises. Multipronged information security is the key to economic security. Focusing of the attention on the information aspects of ensuring economic stability and persistency, as the main conditions for the progressive development of the economy, is of scientific interest in deepening knowledge and acquiring the skills of effective government regulation. The concept of "information and economic security" has been introduced: it is a comprehensive system that protects the vital interests of citizens, society and the state in the economic sphere from internal and external information threats. The latter in this definition acquire the status of information and economic threats - a set of conditions, factors and events that determine the effectiveness of internal and external destructive information influences on the economic condition of the country.

State regulation of economic stability and persistency has been examined on the basis of risk analysis of the modern economy: innovation risks, risks associated with the cyclical development of the economy, market risks, information risks, institutional risks. It has been concluded that the modern development of society is characterized by the integration of security aspects of information and economic processes, which transfers public administration in the field of economy to a higher level in terms of efficiency requirements. The interpenetration of information and economic security forms a new field of scientific knowledge that can be used to increase the level of stability and resilience of the economy. Improvement of the public administration should include: overcoming of the legislation declarative nature and reducing the of gap between legislation and practice in the information and economic sphere, creation of new institutions that define the framework of interaction and rules dealing with ensuring of the economy stability and persistency.

The direction of further research should be determination of the indicators of economic security assessment, including indicators that indicate possible dangers and threats in the information sphere.

Key words: Information security, economic security, information and economic security, economic stability, economic persistency. 
Постановка проблеми в загальному вигляді. Процеси глобалізації в умовах сучасної фінансово-політичної нестабільності й економічної кризи, динамічність явищ у більшості сфер суспільного розвитку, жорстка конкуренція та мінливість зовнішнього середовища $€$ чинниками загроз національній безпеці. Економічна складова частина останньої, яка по суті є визначальною, - динамічна система, що залежить від багатьох зовнішніх та внутрішніх чинників. Їх дослідження має бути пріоритетним для ухвалення державних управлінських рішень, спрямованих на утримання стійкості системи, здатність повертатися в рівноважний стан після зовнішніх і внутрішніх збурень.

У сучасних умовах ухвалення якісних і своєчасних управлінських рішень формується на основі ретельного і всебічного аналізу інформації, що надходить як із внутрішнього, так і із зовнішнього середовища. Інформаційна економіка формулює нові правила господарювання у процесах виробництва, розподілу і споживання суспільних благ. Вона орієнтована на стрімке зростання інформаційних ресурсів, на постійну зміну зовнішньої обстановки, відрізняється мобільністю і не може розвиватися без широкого використання інформаційно-комунікаційних технологій. Отже, інформаційно-економічне середовище набуває все більшого значення, тому потребує захисту від несанкціонованого або ненавмисного впливу на рівні держави, регіону, навіть окремих підприємств. Комплексна інформаційна безпека виступає запорукою гарантування економічної безпеки. Зосередження фокуса уваги на інформаційних аспектах забезпечення економічної стабільності та стійкості як основних умов прогресивного розвитку економіки становить науковий інтерес щодо поглиблення знань, набуття умінь дієвого державного регулювання.

Аналіз останніх досліджень і публікацій. Інформаційну безпеку, проблеми захисту національного інформаційного простору досліджували у своїх роботах О. Панченко [1-3], У. Ільницька [4], Ю. Лісовська [5], Ю. Муравська [6], А. Марущак [7] та інші. Дослідженням питань системи економічної безпеки присвячені багато праць, серед яких роботи таких учених, як П. Друкер, К. МакКоннел, Й. Шумпетер та інші. Економічна безпека досліджується також у працях вітчизняних науковців (О. Барановський, А. Гальчинський, Т. Клєбанова, О. Малиновська, А. Мокій, В. Шлемко й інші). Робіт, у яких вивчають взаємозв'язок інформаційної й економічної безпеки, порівняно мало. Можна виділити таких авторів, як Р. Тимаєв [8], М. Колбанев [9],
Т. Микитенко [10], В. Нехай [11]. Однак їхні дослідження або спрямовані на дуже вузьку тематику, або не досягають потрібної для даного дослідження повноти.

Теоретичні засади економічної стабільності та стійкості досліджувались у низці наукових робіт [12-15]. Їх аналіз не надав достатньої інформації щодо інформаційних чинників у їх регулюванні.

Мета статті. Встановити взаємозв'язок понять «інформаційна безпека», «економічна стабільність», «економічна стійкість» крізь призму економічної безпеки для вироблення дієвих заходів державного регулювання у сфері економіки.

Виклад основного матеріалу. Процес глобалізації в умовах сучасної фінансово-політичної нестабільності й економічної кризи, динамічність розвитку більшості сфер життедіяльності, жорстка конкуренція та мінливість зовнішнього середовища загрожують поступальному розвитку держави. У цих умовах пріоритетним завданням економістів-науковців були і $€$ стабільність та стійкість економічної системи. Ці поняття часто ототожнюють одне з одним і поняттям «економічна безпека». Проте між ними є відмінності і навіть причинно-наслідковий зв'язок, у якому, залежно від ракурсу розгляду та динаміки процесів, фокус уваги може бути зосереджений на одному із трьох.

Трактування економічної стабільності $€$ досить широким і розгалуженим. Сам термін «стабільність» (лат. stabilis) запозичений із природничих наук, де він означає стійкий стан, здатність до тривалого існування, збереження в часі. На практиці точність його визначення досягається завдяки виділенню різних окремих видів стабільності. Стабільність асоціюється з порядком, незмінністю, рівновагою, стійким функціонуванням тощо. Поняття «стабільність» уживається для опису стану системи, її структури й окремих елементів або підсистем, процесів та відносин. В економічній площині - це сталий стан або стан рівноваги всіх елементів економічної системи, у якому вона зберігає незмінною свою структуру.

Економічна стійкість - це здатність зберігати показники на певному рівні, незважаючи на постійний вплив зовнішнього та внутрішнього середовища. Стійкість виступає ознакою «життєдіяльності» системи - здатності системи досягати своєї мети, з урахуванням зміни внутрішніх та зовнішніх чинників, що приводить зазвичай до вдосконалення ії структурного та функціонального змісту.

Щодо сутності економічної безпеки, то вона розглядається як характеристика системи, що самоорганізується і саморозвивається, 
тобто це стан, у якому економічні параметри дозволяють зберегти головні властивості системи: рівновагу і стійкість за мінімізації загроз. Це визначення трактує економічну безпеку у статичному вигляді. Т. Микитенко наводить таке визначення: «Економічна безпека - стан національної економіки, який дозволяє зберігати стійкість до внутрішніх і зовнішніх загроз, що сприяє створенню надійної та забезпеченої всіма необхідними засобами держави, захищеності національно-державних інтересів у сфері економіки». Л. Абалкін розглядає економічну безпеку як «сукупність умов і факторів, що забезпечують незалежність національної економіки, її стабільність і стійкість, здатність до постійного відновлення і самовдосконалення» [16]. Останнє визначення зводить до купи всі три поняття, що розглядаються, тобто вони перебувають в одній площині, де важко визначити пріоритет якогось із них. У Методичних рекомендаціях щодо розрахунку рівня економічної безпеки України (2013 р.) вказується, що «економічна безпека - це стан національної економіки, який дає змогу зберігати стійкість до внутрішніх та зовнішніх загроз, забезпечувати високу конкурентоспроможність у світовому економічному середовищі і характеризує здатність національної економіки до сталого та збалансованого зростання. Складовими економічної безпеки є: виробнича, демографічна, енергетична, зовнішньоекономічна, інвестиційно-інноваційна, макроекономічна, продовольча, соціальна, фінансова безпеки» [17]. Якщо критично розглянути цю цитату, варто відзначити, що: по-перше, економічна безпека знову розглядається як «стан», тобто у статичному вигляді (хоча деякі натяки на динамічність уже наявні у слові «забезпечувати»); по-друге, серед складових частин економічної безпеки не зазначена «інформаційна безпека».

Отже, нами була висунута гіпотеза, що значущість економічної безпеки може бути піднята, якщо розглядати її не тільки у статичному, але й у динамічному вигляді. Тоді вона переміщається у більш вищу площину щодо «стабільності» та «стійкості», тобто стає суб'єктом (засобом) їх забезпечення. Крім цього, порівняння динамічних станів економічної й інформаційної безпеки дає змогу виявити їхній взаємозв'язок та взаємовплив.

Для підтвердження гіпотези наведемо два визначення економічної безпеки. Так, на думку T. Сак, економічна безпека - це свого роду забезпечення в довгостроковій перспективі таких систем показників, як [18]:

- економічна незалежність (фінансова, сировинно-ресурсна, інноваційна тощо);
- економічна стабільність (рівень розвитку, що гарантує відчуття безпеки сьогодні та в майбутньому);

- економічний розвиток (інноваційно-інвестиційна активність, реструктуризація, фінансове оздоровлення).

Такий підхід до трактування суті економічної безпеки відображає її основне функціональне значення: збереження економічної самостійності та досягнутого рівня, а також підвищення конкурентоспроможності й розширення можливостей подальшого розвитку.

Інше визначення, яке, на нашу думку, $€$ досить виваженим, викладене у джерелі [19]: «Економічна безпека - це характеристика стану і динаміки розвитку національної економіки, що виражає її стабільність, стійкість, незалежність, захищеність в умовах впливу внутрішніх і зовнішніх загроз, що забезпечується достатністю накопиченого економічного потенціалу й ефективністю його використання, стійким економічним зростанням, ефективністю і якістю економічних інститутів». Дане трактування інтегрує статичний і динамічний підходи до економічної безпеки, а також підкреслює основні чинники, що забезпечують необхідний рівень економічної безпеки держави і володіють взаємозалежністю. Серед них виділяємо економічний потенціал, що забезпечує стабільність та стійкість, та потенціал інституційного середовища, необхідність використання якого зумовлена тим, що інституційні механізми здатні забезпечувати підвищення рівня економічної безпеки, протидіяти виникненню й розвитку кризових ситуацій, стимулювати найбільш повне використання економічного потенціалу.

Найбільш релевантним з погляду динамічного підходу у визначенні інформаційної безпеки є визначення А. Урсул, Т. Цирдя [20]: інформаційна безпека - «здатність держави, суспільства, соціальної групи, особистості, по-перше, забезпечити з певною ймовірністю достатні і захищені соціальний інтелект та інформаційний ресурс, оптимальну соціальну ентропію й інформаційне середовище для підтримки життєдіяльності та життєздатності, стійкого функціонування і розвитку соціуму; по-друге, протистояти інформаційним небезпекам і загрозам, негативним інформаційним впливам на індивідуальну і суспільну свідомість і психіку людей, а також на комп'ютерні мережі й інші технічні джерела інформації; по-третє, виробляти особистісні та групові навички та вміння безпечної поведінки; по-четверте, підтримувати постійну готовність до адекватних заходів в інформаційному протиборстві, ким би воно не було нав'язане; по-п'яте, постійно 
і послідовно за певною безпечною програмою «вмонтувати» штучний інтелект у суспільне середовище».

Морфологічний аналіз інтерпретацій економічної й інформаційної безпеки дозволяє зробити висновок, що обидва поняття мають багато спільного. Якщо вибрати ключові складники, що формують семантичне ядро обох понять, можна інтегрувати їх в одну структуру. На цю думку наводять і такі міркування. Якщо вважати, що об'єктом економічної безпеки є економічна система держави, її стабільність і стійкість, то в умовах глобальної інформатизації особливого значення набувають інформаційні чинники економічної безпеки: формування інформаційної економіки, зростання ролі інформації, інформаційних ресурсів і технологій у розвитку сучасної економіки. Водночас процес інформатизації створює загалом не тільки нові можливості, але і нові проблеми і загрози, на підставі чого можна зробити висновок про дуалізм впливу інформаційних чинників на економічну безпеку держави. 3 одного боку, розвиток інформаційних технологій підвищує ефективність використання всіх економічних ресурсів, дозволяє забезпечити економічне зростання, налагодити раціональне управління суспільними процесами, підвищити рівень і якість життя. 3 іншого боку, інформатизація породжує нові загрози для розвитку економіки, зумовлені зростанням її залежності від безпеки використовуваних інформаційних технологій, що негативно впливає на економічну безпеку держави, особистості, актуалізує проблему гарантування економічної безпеки в інформаційній сфері.

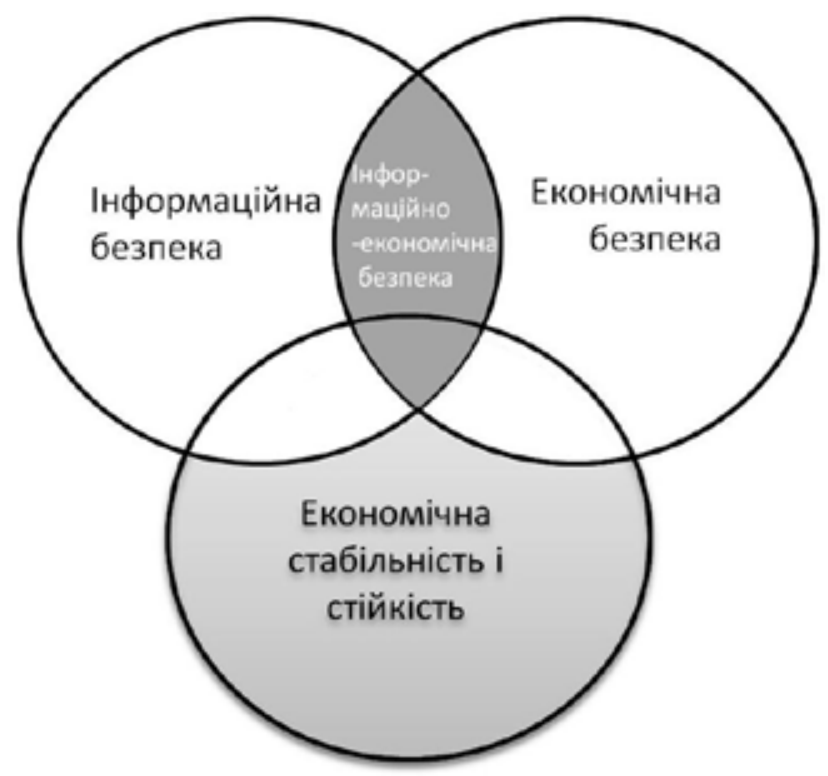

Рис. 1. Взаємозв'язок понять в економічній системі
3 урахуванням вищевикладеного пропонується ввести поняття «інформаційно-економічна безпека» - комплексна система, що забезпечує захист життєво важливих інтересів громадян, суспільства та держави в економічній сфері від внутрішніх і зовнішніх інформаційних загроз. Останні в такому визначенні набувають статусу інформаційно-економічних загроз - сукупності умов, чинників і подій, яка визначає ефективність внутрішніх і зовнішніх деструктивних інформаційних впливів на економічний стан країни.

Підсумовуючи цю частину викладеного матеріалу, пропонуємо модель взаємозв'язку розглянутих понять (рис. 1).

Державне регулюванні економічної стабільності та стійкості може бути розглянуте на основі аналізу ризиків сучасної економіки за версією М. Ческидова (модель «дерева ризиків») (рис. 2).

Аналіз ризиків свідчить про те, що більшість із них тією чи іншою мірою зумовлені інформаційними чинниками, отже, управління ризиками має бути зосереджене на максимальній увазі до них.

Інноваційні ризики. Інформаційні технології є базовими в основі широкого спектра наукомісткої продукції. Без них не можуть існувати ні нанотехнології, ні біотехнології, ні озброєння. Сучасні інформаційні технології це «локомотив» для розвитку всієї сукупності нових технологій. Отже, державне управління має бути спрямоване на підвищення наукоємності і конкурентоспроможності продукції, максимальну взаємодію між наукою і реальним сектором.

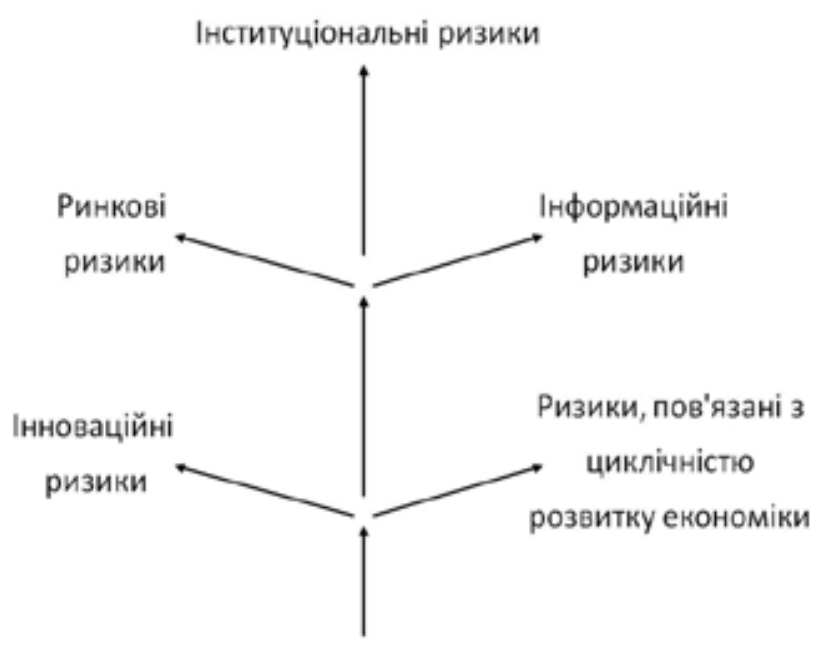

Рис. 2. Ризики сучасної економіки 
Ризики, пов'язані із циклічністю розвитку економіки. Інформаційні технології поряд зі зрушеннями в суспільному розподілі праці, розвитком науково-технічного прогресу, глобалізацією капіталу тощо є однією із причин циклічних трансформацій у сучасній економіці. Державне управління має зосередитись на дієвому прогнозуванні негативних тенденцій, пов'язаних із нестабільністю та нестійким трендом розвитку.

Ринкові ризики. Упровадження інформаційно-комунікаційних технологій у діяльність економічних суб'єктів веде до підсилення їхньої взаємозалежності, формування міжкорпоративних мереж і мережевого монополізму, появи нових форм конкурентної боротьби з використанням інформаційних технологій тощо. Головною управлінською функцією держави має стати формування чесних ринкових відносин, недопущення інформаційної війни як форми конкурентної боротьби.

Інформаційні ризики. До головних варто віднести втрату інформаційної безпеки, інформаційну колонізацію, інформаційну війну як ідеологічний захват. Якщо контролювати потоки інформації, керувати її подачею, в умовах інформаційної економіки можна мати значний вплив на перебіг економічних процесів. Саме тому сучасні технології економічного протиборства переміщаються із традиційного простору в інформаційно-мережевий, або кіберпростір, що зумовлює розширення практики інформаційних воєн.

Забезпечення економічної стабільності та стійкості в умовах інформаційної економіки це досить нова державна функція із ще не встановленим обсягом і змістом методів та інструментів. Ї̈̈ формування зумовлене необхідністю захисту національної економіки від загроз, що виникають в інформаційній сфері, пов'язаних із розвитком новітніх інформаційно-комунікаційних технологій та інтернету. Тому основне завдання полягає в тому, щоб усебічно оцінити їх, глибоко зрозуміти і вивести на рівень проблеми з подальшим розробленням системи комплексних заходів щодо запобігання їм та нейтралізації. Серед актуальних завдань варто виділити:

- розвиток науково обґрунтованих поглядів на взаємопроникнення економічних та інформаційних процесів на новому етапі розвитку суспільства;

- вивчення сутності перспективних інформаційно-економічних загроз та ризиків, що дозволить своєчасно й об'єктивно прогнозувати погіршення інформаційно-економічної обстановки і можливі збитки;
- побудову ефективних концепцій інформаційної протидії в економічній сфері;

- створення перспективних інформаційних продуктів, інформаційних технологій і засобів автоматизації, що забезпечить надійність функціонування державних і суспільних інформаційно-комунікаційних систем та інформаційної інфраструктури країни.

Інституціональні ризики. Інформаційні технології можуть бути причиною порушення прав інтелектуальної власності в мережі Інтернет, появи нових форм опортунізму недобросовісної поведінки, що має на меті отримання односторонньої вигоди, отже, порушує умови угоди. За різними визначеннями опортунізм - це [21]:

- розбіжність інтересів контрагентів;

- недотримання або порушення укладеної угоди;

- інформаційна асиметрія, яка полягає в наявності інформаційної переваги в однієї зі сторін;

- прихований характер поведінки: економічний агент не афішує свою діяльність, інакше склалася б ситуація відкритого зіткнення інтересів, яка відразу може бути врегульована;

- навмисний характер поведінки: для економічного суб'єкта сутність його дій очевидна;

- перерозподіл ресурсів: недобросовісність одного з учасників договору призводить до зростання витрат іншого внаслідок завданих збитків.

Ще одним ризиком $є$ те, що у склад показників економічної безпеки, про які ми говорили вище, досі не включені інформаційні чинники, що ставить під сумнів ефективність державного регулювання стабільності і стійкості економіки.

В умовах інформаційної економіки інституціональний механізм забезпечення економічної стабільності та стійкості повинен включати такі необхідні елементи, як: розроблення нових законів, що враховують інтереси всіх категорій суб'єктів інформаційних відносин; забезпечення балансу творчих і обмежувальних законів в інформаційній сфері, інтеграцію країни у світовий правовий простір, зважання на сучасний стан вітчизняних інформаційних технологій. Удосконалення інституціонального механізму повинно включати: подолання декларативного характеру законодавства, скорочення розриву між законодавством і практикою в інформаційній сфері, формування наднаціонального законодавства в інформаційній сфері, створення нових інститутів, що визначають рамки взаємодії і правил поведінки в інтернет-просторі («електронний кордон», «електронний суве- 
ренітет», «електронний податок» тощо), розвиток приватно-державного партнерства в інформаційній сфері.

Висновки. Сучасний розвиток суспільства характеризується інтеграцією безпекових аспектів інформаційних та економічних процесів, що переводить державне управління у сфері економіки на більш високий рівень за вимогами до ефективності.

Взаємопроникнення інформаційної й економічної безпеки формує нову сферу наукових знань, що можуть бути задіяні для підвищення рівня стабільності та стійкості економіки.

Удосконалення державного управління повинно включати: подолання декларативного характеру законодавства, скорочення розриву між законодавством і практикою в інформаційно-економічній сфері, створення нових інститутів, що визначають рамки взаємодії і правил поведінки щодо забезпечення стабільності та стійкості економіки.

Напрямом подальшого дослідження має стати визначення показників оцінки економічної безпеки, включаючи індикатори, що сигналізують про можливі небезпеки і загрози в інформаційній сфері.

\section{ЛІТЕРАТУРА:}

1. Панченко О., Банчук Н. Информационная безопасность личности : монография. Киев : КИТ, 2011. 672 c.

2. Панченко О. Информационно-психологическая безопасность в эпоху турбулентности : монографрия. Киев : КВИЦ, 2020. 472 с.

3. Панченко О. Інфрормаційна безпека в епоху турбулентності: державно-управлінський аспект : монограсрія. Київ : КВІЦ, 2020. 332 с.

4. Ільницька У. Інформаційна безпека України: сучасні виклики, загрози та механізми протидії негативним інорормаційно-психологічним впливам. Політичні науки. 2016. Вип. 2. № 1. С. 27-32.

5. Лисовская Ю. Инфрормационная безопасность в современном глобализованном мире. Вестник Белорусского государственного университета. 2015. № 2. С. 93-97.

6. Муравська (Якубівська) Ю. Інформаційна безпека суспільства : концептуальний аналіз. Економіка і суспільство. 2017. Вип. № 9. С. 289-294.

7. Марущак А. Дослідження проблем інфрормаційної безпеки у юридичній науці. Правова інформатика. 2010. № 3 (27). С. 17-21.

8. Тимаев Р. Понятие информационно-экономической безопасности предприятия. URL: http://dspace. nbuv.gov.ua/bitstream/handle/123456789/93810/16Timaev.pdf?sequence=1 (дата звернення: 26.12.2020).

9. Колбанев М., Коршунов И., Левкин И. Информатизация и информационно-экономическая безопасность. Россия и Санкт-Петербург: экономика и образование в XXI в. : сборник докладов. Санкт-Петербург : Санкт-Петербургский государственный экономический университет, 2016.
C. 159 Веснік БДУ 163. URL: https://elibrary.ru/item. asp?id=27484674\& (дата звернення: 26.12.2020).

10. Проблеми інформаційної безпеки суб'єктів господарювання в Україні та можливі шляхи їх вирішення в сучасних умовах / Т. Микитенко та ін. Збірник наукових праць Центру воєнно-стратегічних досліджень Національного університету оборони України імені Івана Черняховського. 2016. URL: http:// znp-cvsd.nuou.org.ua/article/download/126694/121598 (дата звернення: 26.12.2020).

11. Нехай В., Нехай В. Інформаційна безпека як складова економічної безпеки підприємств. Науковий вісник Міжнародного гуманітарного універcumemy. 2017. URL: http://www.vestnik-econom. mgu.od.ua/journal/2017/24-2-2017/30.pdf (дата звернення: 26.12.2020).

12. Шубровська О. Сталий економічний розвиток: поняття і напрям досліджень. Економіка України. 2005. № 1. С. 36 Веснік БДУ 42.

13. Ячменьова В. Економічна стабільність: сутність та форми вияву. Економіка. Менеджмент. Підприємництво. 2012. № 224 (II). С. 94-99.

14. Карачина Н., Сорока Л. Теоретико-методичні засади визначення та оцінювання економічної стабільності підприємств. Ефрективна економіка : електронний журнал. 2015. № 11. URL: http://www.economy.nayka.com.ua/?op=1\&z=4487 (дата звернення: 26.12.2020).

15. Поверляк Т. Визначення понять «економічна стабільність» та «економічна стійкість». Advanced Technologies of Science and Education: XIV Міжнародна наукова інтернет-конференція. URL: http://intkonf.org/poverlyak-t-i-viznachennya-ponyatekonomichna-stabilnist-ta-ekonomichna-stiykist/ (дата звернення: 26.12.2020).

16. Абалкин Л. Экономическая безопасность России : угрозы и их отражение. Вопросы экономики. 1994. № 12. C. 4-13.

17. Про затвердження методичних рекомендацій щодо розрахунку рівня економічної безпеки України : наказ від 29 жовтня 2013 р. № 1277 / Міністерство економічного розвитку і торгівлі України. URL: https:// zakon.rada.gov.ua/rada/show/v1277731-13\#text (дата звернення: 26.12.2020).

18. Сак Т. Економічна безпека України: поняття, структура, основні тенденції. Інноваційна економіка. 2013. № 6 (44). С. 336-340.

19. Ческидов М. Экономическая безопасность государства в условиях инсрормационной экономики : авторефр. дис. Саратов, 2013. URL: https://www. dissercat.com/content/ekonomicheskaya-bezopasnostgosudarstva-v-usloviyakh-informatsionnoi-ekonomiki (дата звернення: 26.12.2020).

20. Урсул А., Цырдя Т. Информационная безопасность. Сущность, содержание и принципы ее обеспечения. URL: http://security.ase.md/publ/ru/pubruhtml (дата звернення: 27.12.2020).

21. Тутов Л., Лозина О. Оппортунистическое поведение человека в современной экономике : междисциплинарный подход. Государственное управление : электронный вестник. URL: https://cyberleninka. ru/article/n/opportunisticheskoe-povedenie-chelovekav-sovremennoy-ekonomike-mezhdistsiplinarnyypodhod/viewer (дата звернення: 27.12.2020). 